\title{
Effects of the bioturbating lugworm Arenicola marina on the structure of benthic protistan communities
}

\author{
Matthias Engel ${ }^{1}$, Anke Behnke ${ }^{1}$, Julia Klier ${ }^{1}$, Christian Buschbaum ${ }^{2}$, \\ Nils Volkenborn ${ }^{3}$, Thorsten Stoeck ${ }^{1, *}$ \\ ${ }^{1}$ Department of Ecology, University of Kaiserslautern, 67653 Kaiserslautern, Germany \\ ${ }^{2}$ Alfred-Wegener-Institut für Polar- und Meeresforschung, Wadden Sea Station Sylt, 25992 List/Sylt, Germany \\ ${ }^{3}$ Department of Biological Sciences, University of South Carolina, Columbia, South Carolina 29208, USA
}

\begin{abstract}
Sedimentary coastal ecosystems like the European Wadden Sea in the northeastern Atlantic harbor large populations of burrowing infauna, such as arenicolide polychaetes. These 'ecosystem engineering' macrofaunal organisms destabilize sediments by reworking and irrigating them, leading to a reorganization of sediment physicochemical state and bacterial communities. Here, we tested the effects of the lugworm Arenicola marina on intertidal psammophilic protistan community diversity and structure in a field experiment. We applied pyrosequencing and community structure analyses to samples in which we manipulated lugworm densities. Irrespective of the presence or absence of the lugworm, protistan abundance and diversity (mostly diatoms and ciliates) was higher in oxic surface sediments compared to anoxic subsurface sediments. In the presence of A. marina, protistan abundances and diversity decreased decisively in surface as well as in subsurface bulk sediment. Also, the protistan community composition differed remarkably, with only $28 \%$ of all phylotypes $\left(\mathrm{n}_{\text {total }}=855\right)$ shared between habitats with and without lugworms. Twenty-seven percent of all taxa were detected exclusively in the presence of lugworms, and $62 \%$ of the taxa found in the oxic subsurface sediment surrounding the lugworm burrow were limited to this distinct microenvironment. This suggests that lugworm burrows provide an ecological niche potentially hosting protist taxa that are adapted to fluctuating oxygen supply. We conclude that though the activities of $A$. marina reduce the overall abundance of protists, they select for very specific and well-adapted taxa. This adds to the overall protistan diversity in intertidal sandflats on larger spatial scales. Most likely, the observed effects of lugworms on protistan community structure and composition are due to a combination of direct trophic and indirect sediment-mediated effects, such as disturbance by reworking the sediment, oxygen supply by burrow ventilation and increased pore water exchange due to bioadvection.
\end{abstract}

KEY WORDS: Benthos · Diversity $\cdot$ Distribution patterns $\cdot$ Grazing $\cdot$ Macroinvertebrates $\cdot$ Protist $\cdot$ Sediment incubation

Resale or republication not permitted without written consent of the publisher

\section{INTRODUCTION}

Protists are key components in intertidal sedimentary ecosystems. Photosynthetic protists, e.g. diatoms, are producers of substantial biomass, while heterotrophs, e.g. ciliates and flagellates play a cru- cial role in benthic food webs (Epstein 1997, Wickham et al. 2000, Hamels et al. 2001). They are consumers of microorganisms including other protists and are at the same time grazed by benthic invertebrates such as filter-feeding bivalves (Le Gall et al. 1997), thus representing a link between lower (bac- 
teria) and higher (metazoa) trophic levels. Despite their importance for the functioning and productivity of benthic systems, our current knowledge of protistan diversity, community structure, and distribution in sediments is lacking (Wickham et al. 2000, Lei et al. 2010). One main reason for this is that many protists escape microscopic detection and identification. Recent advances in molecular techniques have uncovered an enormous genetic diversity within benthic protistan communities, yet how this diversity relates to environmental parameters is largely unknown.

Marine sediments are characterized by steep geochemical gradients and thus offer a very heterogeneous habitat for protists (Ranjard \& Richaume 2001, Franklin \& Mills 2003). Oxygen is only present in the uppermost sediment layer (typically millimeters to a few centimeters thick, depending on grain size, sedimentary oxygen consumption, physical advection, and oxygen production by microphytobenthos), while the subsurface is anoxic (Fenchel \& Finlay 1995). Infaunal macroinvertebrates perturb this pattern. Their ventilating and sediment-reworking activities create a mosaic of spatially heterogeneous and temporally dynamic geochemical conditions (Aller 1982, 1988, 1994). With respect to prokaryotic communities, there is evidence that infaunal burrows host distinct microbial assemblages when compared to the anoxic surrounding sediment as well as to the surficial oxic sediment (Steward et al. 1996, Matsui et al. 2004, Kristensen \& Kostka 2005, Papaspyrou et al. 2005; but see also Bertics \& Ziebis 2009). Also, there is evidence that infaunal burrows attract small zoobenthos (Reise 1981, 1983, 1987). Much less is known about the role of infaunal bioturbation for the protistan community (Lei et al. 2010).

We used the lugworm Arenicola marina as a model organism to investigate the role of bioturbating infauna in the structure of the benthic protistan community and the distribution of protistan phylotypes. Lugworms are abundant on intertidal flats in the Wadden Sea, where they create up to $40 \mathrm{~cm}$ deep Jshaped blind-ending burrows (Riisgård \& Banta 1998). Lugworm bioturbation has significant effects on many sedimentary processes, including stratification (Baumfalk 1979), pore water characteristics (Hüttel 1990, Volkenborn et al. 2007a), sediment biogeochemistry (Banta et al. 1999, Kristensen 2001, Nielsen et al. 2003, Volkenborn et al. 2010), microbial communities (Reichardt 1988, Grossmann \& Reichardt 1991, Retraubun et al. 1996), meiobenthic communities (Reise \& Ax 1979, Reise 1987, Kuhnert et al. 2010, Lei et al. 2010), and macrobenthic communities (Reise 1983, Flach 1992, Volkenborn \&
Reise 2006, Valdemarsen et al. 2011). The potential impact of lugworms on the protistan community is expected to be manifold and include direct trophic effects and indirect sediment-mediated effects. The direct trophic impact is expected based on the feeding behavior of lugworms. Lugworms are relatively unselective deposit feeders that ingest large volumes of sediment including the associated protists (Zebe \& Schiedek 1996). Specifically, diatoms are a dominant component of the lugworm diet (Grossmann \& Reichardt 1991, Retraubun et al. 1996). Beside this direct impact of grazing, lugworms are likely to affect the distribution and abundance of protists through habitat modification, which operates on different spatial and temporal scales. As ecosystem engineers, they have a profound impact on sediment and pore water characteristics and dynamics (Hüttel 1990, Volkenborn et al. 2007a). Dense populations of these polychaetes keep sediments sandy and permeable with relatively low organic content and pore water nutrient concentrations (Volkenborn et al. $2007 \mathrm{~b}$ ). On the scale of individual burrows, potential effects of the lugworms on protists are directly related to their bioturbating activities, i.e. sediment reworking, burrow ventilation, and irrigation of the sediment surrounding the burrow (pore water bioadvection). Sediment reworking includes the subduction of surface material to depth (Retraubun et al. 1996) and the deposition of the digested material onto the sediment surface in characteristic fecal mounds, which are frequently dispersed by tidal currents and wave action. Thus, living conditions for protistan communities in lugworm-populated intertidal sediments may vary strongly in space and time.

Burrow ventilation results in substantial advection of oxic water into the burrow and surrounding sediment (Meysman et al. 2005, Timmermann et al. 2006, $\mathrm{Na}$ et al. 2008, Wethey et al. 2008). However, due to the intermittency of lugworm ventilation, pore water bioadvection is unsteady. Additionally, the sediment surrounding lugworm burrows frequently oscillates between oxic and anoxic conditions on the scale of minutes to hours with the spatial scale of impact strongly dependent upon the sediment type (Volkenborn et al. 2010).

We ran a short-term (6 wk) and small-scale $(40 \times$ $40 \mathrm{~cm}$ ) field experiment, in which we analyzed the genetic protistan diversity in oxic surface and anoxic subsurface sediments in the presence and absence of lugworms, as well as in subsurface sediments oxidized by lugworm activity. We used molecular (highresolution next generation 454 sequencing of taxonomic marker genes) and statistical analyses. Our 
objective was to compare the community structures between different habitats and to identify whether specific zones are characterized by unique or shared protistan phylotypes.

\section{MATERIALS AND METHODS}

\section{Sampling site and procedure}

The influence of the lugworm Arenicola marina on benthic protists was explored in a field experiment between June and July 2010 on an intertidal flat near the island of Sylt, Germany. The experimental site ('Oddewatt'; $55^{\circ} 01^{\prime} 30.51 " \mathrm{~N}, 8^{\circ} 26^{\prime} 10.25^{\prime \prime} \mathrm{E}$ ) was densely populated by adult lugworms ( $>40$ individuals [ind.] $\mathrm{m}^{-2}$ ). The muddy sand sediment (permeability $K=4 \times 10^{-12} \mathrm{~m}^{2}$, porosity $=0.4$ ) was characterized by low organic content $(<1 \%$ of weight by loss after ignition). Time without water coverage was approximately $5 \mathrm{~h}$ per low tide. Oxygen concentrations were not measured in the different sediment types, as the sediment color usually gives sufficient information on oxygen regimes in sediments. As depicted in Fig. 1, our samples consisted of 2 basic sediment types: light brown colored sediment on the surface and in the immediate surroundings of the lugworm burrows, and dark colored (black iron sulfide precipitates) subsurface sediment. The latter

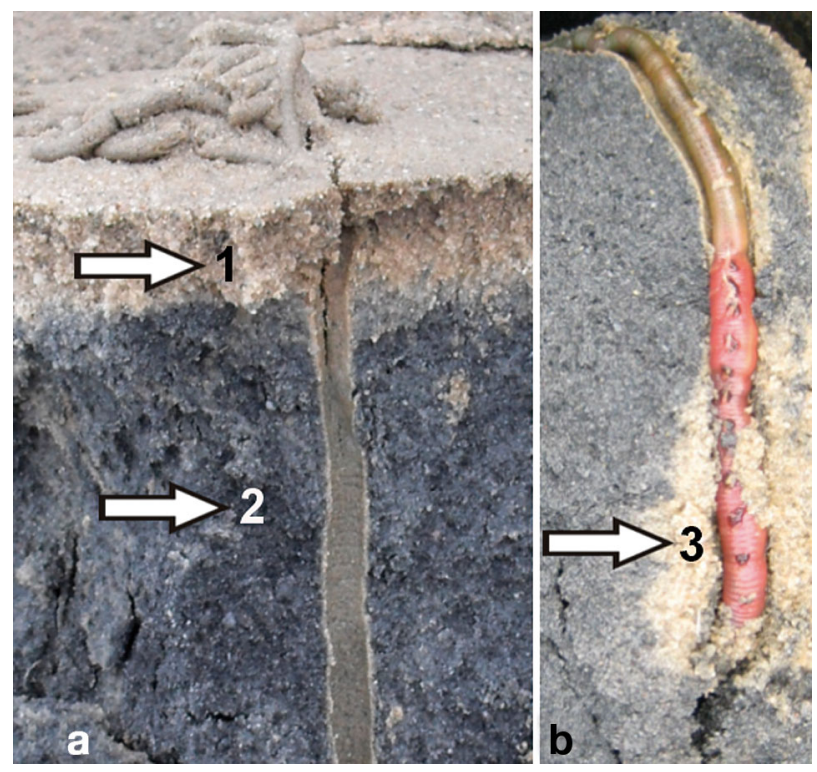

Fig. 1. Origin of the 3 different sediment samples analyzed. Numbers indicate the 3 sampling niches: (a) $1=$ oxic surface sediment, 2 = anoxic subsurface sediment, (b) 3 = oxic sediment surrounding the lugworm burrow. For details on sediment descriptions see 'Materials and methods' was characterized by a considerable sulfidic smell. These characteristics point to oxic conditions in brownish surface/burrow sediments and anoxic conditions in black sulfidic subsurface sediments. This is in accordance with the general finding that marine sediments are typically oxic on the surface (within the first few $\mathrm{mm}$ to $\mathrm{cm}$ ) and anoxic in the subsurface (Fenchel \& Finlay 1995).

In six $40 \times 40 \mathrm{~cm}$ areas we inserted a $1 \mathrm{~mm}$ polyethylene mesh horizontally at approximately $10 \mathrm{~cm}$ depth to exclude lugworms permanently, as has been successfully done in previous studies (Reise 1983, Volkenborn \& Reise 2006). A circular hole was cut in the horizontal mesh and a plastic core $(18 \mathrm{~cm}$ inner diameter) was gently pushed through the cut-out into the sediment to a depth of $25 \mathrm{~cm}$ and the enclosed sediment was excavated. Circular mesh bags $(18 \mathrm{~cm}$ diameter, $25 \mathrm{~cm}$ deep, $1 \mathrm{~mm}$ mesh size) were filled with sieved ( $5 \mathrm{~mm}$ mesh) and homogenized subsurface sediment from the experimental site, and placed in the center of these exclusion plots flush with the sediment surface. The plastic core was then removed. Three days after the set-up, 8 mediumsized lugworms $(1.4 \pm 0.3 \mathrm{~g}$ individual fresh weight; $7.9 \pm 1.1 \mathrm{~cm}$ total length; $5.6 \pm 0.8 \mathrm{~cm}$ body length without tail; mean $\pm \mathrm{SD}, \mathrm{n}=24$ ) were added to each of 3 of the 6 mesh bags (lugworm bags), while the other 3 bags remained lugworm-free (exclusion bags).

After $6 \mathrm{wk}$, sediment from lugworm and exclusion bags was sampled for protistan community analysis. First, the surface sediment (top 1 to $2 \mathrm{~mm}$ ) within each mesh bag was carefully collected with a spatula (Fig. 1). Fresh lugworm fecal casts were avoided when sampling the lugworm bags. Then, the mesh bags were excavated with a shovel and the sediment was carefully broken apart. Anoxic black subsurface sediment samples (Fig. 1) were taken at 10 to $15 \mathrm{~cm}$ depth from lugworm and control bags. Subsurface oxic sediment (brownish, Fig. 1) at 10 to $20 \mathrm{~cm}$ depth, corresponding to lugworm feeding pockets, was collected from the lugworm bags. The numbers of Arenicola marina within the lugworm bags remained steady during the experimental period. At the end of the experiment, 1 lugworm was missing from 2 bags. No lugworms were present in the exclusion bags. Despite the emigration of a lugworm from 2 individual experiments, high-density lugworm patches were maintained in the lugworm bags over the course of the experiment.

Samples from the same locations within treatments were pooled and gently homogenized resulting in 5 distinct sediment types: lugworm surface, exclusion 
surface, lugworm subsurface, exclusion subsurface, and lugworm burrow. In the field, 2 to $3 \mathrm{ml}$ subsamples of all sediment types were mixed with $3 \mathrm{ml}$ RNAlater (Qiagen) to stabilize and preserve RNA. For the determination of protistan and bacterial abundances, samples were fixed with glutaraldehyde (final concentration $1.6 \%$ ) and frozen at $-80^{\circ} \mathrm{C}$ for further processing.

\section{Enumeration of protists}

Enumeration of protists followed the protocol of Sherr and colleagues (Sherr et al. 1993). Briefly, $1 \mathrm{ml}$ of sediment was homogenized with $24 \mathrm{ml}$ of Trizma (pH 8.8, Sigma Aldrich) in a centrifuge tube to separate protists from the sediment. After a few seconds, when the sediment had collected at the bottom of the centrifuge tube, $4 \mathrm{ml}$ of the supernatant were filtered onto a $0.8 \mu \mathrm{m}$ pore sized Isopore filter (Millipore) and stained with DAPI (4,6-diamidino-2-phenylindole, Sigma Aldrich, final concentration $1 \mu \mathrm{g} \mathrm{ml}^{-1}$ ). After a 3 min incubation in the dark, filters were washed with water and ethanol, air dried and mounted with Vectashield filters (Vector Labs) and examined under a epifluorescence microscope (Axioplan 2, Zeiss) at 40- to 100-fold magnification. Three replicate filters were counted per sample. Counting was performed according to standard procedures (Sherr et al. 1993).

\section{RNA extraction and transcription}

Total RNA was extracted from all samples using the AllPrep DNA/RNA Mini kit (Qiagen). The integrity of extracted and purified RNA was checked with the RNA 6000 Pico Assay (Agilent Technologies). PCR amplification using the eukaryoticspecific primer set EukA and Euk516R (Table 1) was used as a control to eliminate the possibility of residual DNA contamination in all individual RNA extracts. Each PCR mixture contained 10 to 20 ng of

Table 1. Eukaryote-specific PCR primers used in this study

\begin{tabular}{|lll|}
\hline Primer & Sequence 5'-3' & Source \\
\hline EukA & AACCTGGTTGATCCTGCCAGT & Medlin et al. (1988) \\
Euk516R & ACCAGACTTGCCCTCC & Amann et al. (1990) \\
Euk360FE & CGGAGA(AG)GG(AC)GC(AC)TGAGA & Medlin et al. (1988) \\
EukB & TGATCCTTCTGCAGGTTCACCTAC & Medlin et al. (1988) \\
TAReukFWD1 & CCAGCA(GC)C(CT)GCGGTAATCC & Stoeck et al. (2010) \\
TAReukREV3 & ACTTTCGTTCTTGAT(CT)(AG)A & Stoeck et al. (2010) \\
\hline
\end{tabular}

template cDNA, 5 U of HotStar Taq DNA polymerase (Qiagen), 1× CoralLoad PCR Buffer (containing $1.5 \mathrm{mM} \mathrm{MgCl} 2), 200 \mathrm{mM}$ of each deoxynucleotide triphosphate (dNTP), and $0.5 \mathrm{mM}$ of each oligonucleotide primer. The final reaction mix was adjusted to a volume of $50 \mu \mathrm{l}$ with sterile water. The PCR amplification protocol consisted of an initial denaturation $\left(5 \mathrm{~min}\right.$ at $95^{\circ} \mathrm{C}$ ) followed by 30 identical amplification cycles (denaturation at $94^{\circ} \mathrm{C}$ for $30 \mathrm{~s}$, annealing at $56^{\circ} \mathrm{C}$ for $30 \mathrm{~s}$ and extension at $72^{\circ} \mathrm{C}$ for $45 \mathrm{~s}$ ) and a final extension at $72^{\circ} \mathrm{C}$ for $5 \mathrm{~min}$. If no DNA contamination was detected, extracted RNA was transcribed into cDNA using the QuantiTect Reverse Transcription kit (Qiagen) following the manufacturer's instructions.

\section{Oligonucleotide primers, PCR amplification and 454 sequencing}

Nearly full-length small subunit (SSU) rRNA genes were PCR amplified by using the eukaryotic-specific primer set Euk360FE and EukB (Table 1) with the same PCR conditions as described above. PCR products were checked by agarose gel electrophoresis $(1 \%)$. For each cDNA sample, we ran 5 individual PCR reactions. The PCR products were cleaned using the MinElute kit (Qiagen) and all products resulting from the same template cDNA were combined. The combined PCR products were used as a template in a second (nested) PCR reaction, which amplified the hypervariable V4 region of the SSU rDNA for subsequent pyrosequencing. The protocol for V4-region amplification has been described by Stoeck et al. (2010) and employs the primer set TAReukFWD1 and TAReukREV3 (Table 1). For the GS-FLX Titanium sequencing, adapters A (5'-CGT ATC GCC TCC CTC GCG CCA-3') and B (5'-CTA TGC GCC TTG CCA GCC CGC-3') were linked to the $5^{\prime}$ end of the forward and reverse primers, respectively. Moreover, to distinguish between the 5 samples, multiplex-identifiers (MID) were linked to each forward primer-sequence complex. PCR mixtures for 454 sequencing reactions contained 2 U of Phusion Hot Start high-fidelity Taq polymerase (New England Biolabs), 5× GCbuffer, $200 \mathrm{mM}$ dNTPs, $0.5 \mathrm{mM}$ of each primer (Table 1) and approximately $1 \mathrm{ng}$ of template DNA in a volume of $50 \mu$ l. The amplification consisted of a qualitative and a quantitative 
step. It comprised an initial activation step at $98^{\circ} \mathrm{C}$ for $10 \mathrm{~s}$, followed by ten 3-step cycles consisting of $94^{\circ} \mathrm{C}$ for $30 \mathrm{~s}, 57^{\circ} \mathrm{C}$ for $45 \mathrm{~s}$, and $72^{\circ} \mathrm{C}$ for $1 \mathrm{~min}$. These were followed by 25 further cycles consisting of $98^{\circ} \mathrm{C}$ for $10 \mathrm{~s}, 52^{\circ} \mathrm{C}$ for $30 \mathrm{~s}$, and $72^{\circ} \mathrm{C}$ for $1 \mathrm{~min}$, and then a final 2 min extension at $72^{\circ} \mathrm{C}$. PCR products were checked on a $1 \%$ low-melting-point agarose gel, excised and cleaned up using the MinElute gel extraction kit (Qiagen). Again, 5 individual PCR reactions per template were run and combined after purification. All tags were sequenced from the $5^{\prime}$ end using the forward primer.

\section{Sequence data processing}

All initial analyses of 454 sequencing data sets were performed with the software package JAguc (Nebel et al. 2011) using the criteria and strategies as described in detail previously (Behnke et al. 2011). Sequence clustering was conducted at a sequence similarity threshold of $97 \%$. For the determination of phylogenetic affiliations of each phylotype we made use of the JAguc-implemented BLAST tool against the SSU rRNA GenBank release (version 2.2.26+).

For subsequent comparative statistical analyses, we did not take single singletons into account, i.e. we manually removed all phylotypes that occurred only once and exclusively in 1 of the 5 samples. Due to the high probability that these phylotypes result from erroneous sequence reads (Quince et al. 2009, Huse et al. 2010, Kunin et al. 2010, Behnke et al. 2011), this procedure is a conservative way of discounting potentially artifactual rare species. Finally, we manually removed all clusters that were identified as nonprotistan phylotypes in BLAST analyses (e.g. metazoan and embryophytan sequences).

\section{Community analyses and comparisons}

To obtain more detailed information about the influence of the lugworm on microbial assemblages, several alpha- and beta-diversity indices were computed with the software package SPADE (Chao \& Shen 2003). The Shannon diversity index (Heip \& Engels 1974) was calculated to explore community diversity and phylotype frequencies within a community (alpha-diversity). For the partitioning of diversity shared between 2 communities (treatments), we calculated the incidence-based Sørensen index as well as the abundance-based Chao-Sørensen index (Chao et al. 2006).

\section{RESULTS}

\section{Protistan abundances}

The presence of lugworms had a clear effect on the total abundances of protists. In the surface and subsurface sediments, protistan abundance was 4 - and 2-times lower in the presence than in the absence of lugworms, respectively (Fig. 2). In the absence of lugworms there was a strong decline in protists from the surface to the subsurface, while the presence of lugworms caused comparatively even protistan abundance distribution in surface, subsurface and lugworm burrow sediment.

\section{Protistan community composition and structure}

Pyrosequencing yielded 33125 amplicons with a total of 20594 sequences remaining after removal of low-quality and non-target sequences. The number of target amplicons is highly unequal among the different treatments, ranging from 890 (lugworm burrow sample) to 8188 (oxic sediment without lugworms). Despite the unequal sample sizes, rarefaction curves revealed saturated sampling for nearly all samples (with the exception of the sample derived from the lugworm burrow) after clustering of target sequences (phylotype calling at $97 \%$ sequence similarity) and removal of singletons (Behnke et al. 2011) (Fig. 3).

Phylotype diversity differed decisively among samples and ranged from 76 different phylotypes in the anoxic subsurface layer of the incubation with lug-

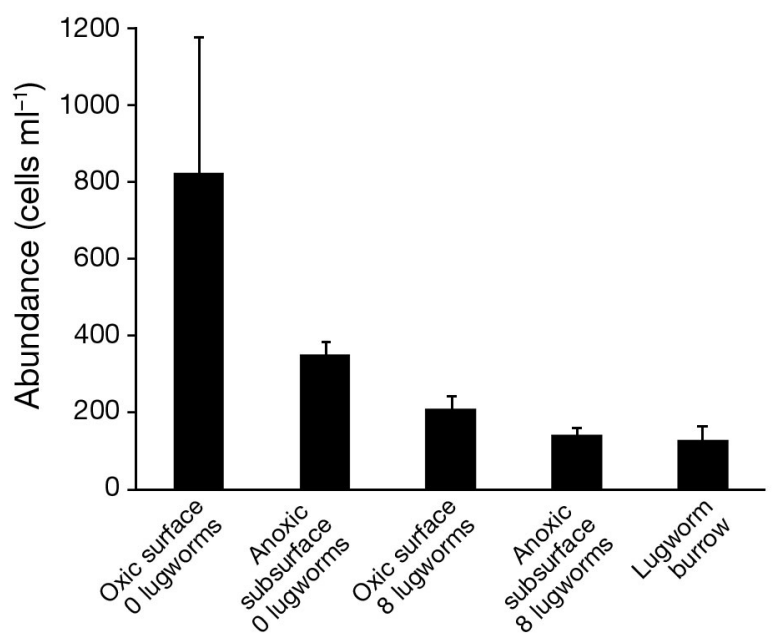

Fig. 2. Protistan abundances in the 5 sediment samples. Each bar represents the average of 3 replicates, error bars are $1 \mathrm{SD}$ of the mean 
worms (anox-8) up to 462 phylotypes in the oxic surface layer without lugworms (oxic-0). Control samples without Arenicola marina were thus much more diverse than samples with lugworms (Shannon index in Table 2). Also, the relative phylotype richness (as indicated by the number of sequence reads per phylotype; Table 2) was decisively higher in the control samples. In samples without the lugworm, protistan diversity was very similar in surface and subsurface samples (Shannon index in Table 2). In contrast, the presence of $A$. marina resulted in an evidently lower protistan diversity and richness in subsurface compared to surface sediments. Interestingly, the lugworm burrow nested within the deeper anoxic subsurface sediment supported a more complex pro-

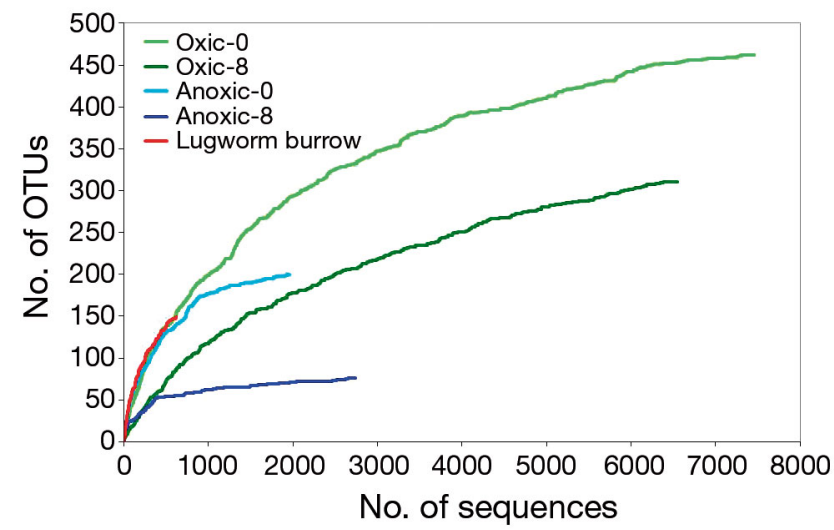

Fig. 3. Sampling saturation curve of the 5 sediment samples analyzed. Analyses were performed at $97 \%$ similarity threshold (singletons eliminated from analysis). All samples apart from the lugworm burrow approach the asymptote (i.e. sample saturation). OTU: operational taxonomic unit; oxic: surface sediment; anoxic: subsurface sediment; 0 : without lugworms; 8: with lugworms tistan community (higher diversity, higher relative phylotype richness) than the adjacent anoxic subsurface sediment.

The protistan phylotype composition differed strongly among sediment samples. In total, 855 phylotypes were identified, with only $28 \%$ of them shared between lugworm-depleted and lugworminhabited sediments (Fig. 4a; Sørensen incidence: 0.4440; abundance: 0.7790 ), while 45 and $27 \%$ of all phylotypes were unique in the absence and presence of lugworms, respectively (Fig. 4a). The overlap of phylotypes between lugworm-free and lugworminhabited sediment was moderate in surficial sediment (34\%) (Fig. 4b; Sørensen incidence: 0.5071; abundance: 0.8560) and marginal in the subsurface (3\%) (Fig. 4c; Sørensen incidence: 0.0652; abundance: 0.2257 ). In the presence of lugworms, very few phylotypes were shared between the different zones (Fig. 4d; oxic surface-8 vs. anoxic subsurface-8, Sørensen incidence 0.0362; abundance: 0.03456; oxic surface-8 vs. lugworm burrow, Sørensen incidence: 0.2299 ; abundance: 0.1123 ; anoxic subsurface-8 vs. lugworm burrow, Sørensen incidence: 0.0442; abundance: 0.1421). Here, the majority of phylotypes $(87 \%)$ were exclusively found in either the surface, the subsurface, or the burrow sediment. This means that $62 \%$ of the 150 phylotypes found within the lugworm burrow were unique to this location.

\section{Taxonomic composition of protistan communities}

Stramenopiles were the most diverse group of organisms in all analyzed sediment samples (Fig. 5,

Table 2. Data overview of the molecular and statistical analyses of protistan communities derived from the 5 sediment samples. The table displays numbers of 454 reads in each sample and the phylotypes called at $97 \%$ sequence similarity. The number of sequence reads per phylotype is a measure of relative phylotype richness in each sample (smaller numbers indicate higher relative phylotype richness), while the Shannon Index is a measure of alpha-diversity (phylotype diversity within a sample)

\begin{tabular}{|c|c|c|c|c|c|c|}
\hline & & $\begin{array}{l}\text { Total sequence } \\
\text { reads obtained } \\
\text { after sequencing }\end{array}$ & $\begin{array}{l}\text { Protistan sequence } \\
\text { reads (non-targets } \\
\text { excluded) }\end{array}$ & Phylotypes $^{\mathrm{a}}$ & $\begin{array}{l}\text { Reads per } \\
\text { phylotype }\end{array}$ & $\begin{array}{c}\text { Shannon } \\
\text { index }\end{array}$ \\
\hline \multicolumn{7}{|c|}{ Control without Arenicola marina } \\
\hline Oxic & Surface sediment & 8618 & 8188 & 462 & 17.7 & 4.3 \\
\hline Anoxic & Subsurface sediment & 4801 & 2167 & 200 & 10.8 & 4.5 \\
\hline \multicolumn{7}{|c|}{ Samples with Arenicola marina } \\
\hline Oxic & Surface sediment & 7355 & 6952 & 311 & 22.4 & 1.9 \\
\hline Anoxic & Subsurface sediment & 6376 & 2397 & 76 & 31.5 & 2.9 \\
\hline \multicolumn{7}{|c|}{ Samples from lugworm burrow } \\
\hline Oxic & Subsurface sediment & 5975 & 890 & 150 & 5.9 & 4.5 \\
\hline
\end{tabular}


Treatments with and without

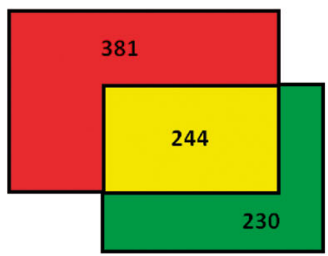

c Treatments with and without lugworms, anoxic subsurface sediments

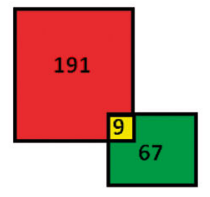

Treatment without lugworms

\begin{abstract}
Treatment with
\end{abstract} 8 lugworms lugworms, total sediments lugworms, oxic surface sediments

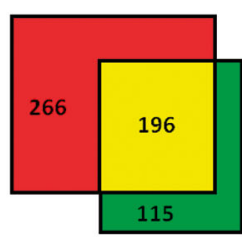

d Treatments with lugworms, oxic surface, anoxic subsurface and lugworm burrow

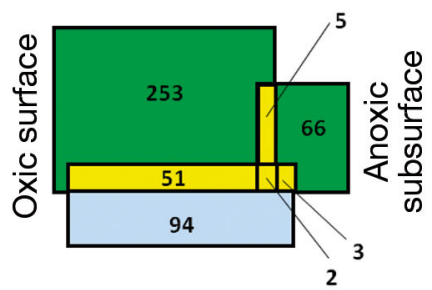

Shared phylotypes
Lugworm b Treatments with and without

The second predominant group of microorganisms were alveolates, accounting for 20 to $40 \%$ of detected phylotypes (anoxic-8 and oxic-0, respectively). The only exception was the unaltered anoxic subsurface sample (anoxic-0) where alveolates only contributed $1.5 \%$ to community diversity (Fig. 5), mirroring at the same time decreasing phylotype numbers from oxic surface towards anoxic subsurface sediments (Fig. 5).

The most diverse group within the alveolates were ciliates, with 73 to $90 \%$ of all alveolate phylotypes (oxic-0 and oxic-8, respectively). Thereby, species like Pleuronema, Chlamydodon, Dysteria and Coleps contributed the most to the overall ciliate community (up to 39 phylotypes, Supplement 1). In anoxic subsurface sediments, ciliate phylotypes occurred only sporadically (1 to 9 phylotypes). Nonetheless, the occurrence of e.g. Cardiostomatella, Cyclidium and Coleps showed an opposite trend to those phylotypes detected in oxic surface sediments. Pleuronema and Trachelocerca (15 and 6 phylotypes, respectively) were the predominant ciliate taxa within the lugworm burrow, contributing $55 \%$ to the total ciliate community.

Supplement 1 at www.int-res.com/articles/suppl/ m471p087_supp.pdf). Their relative contribution to the overall diversity ranged between $52 \%$ of phylotypes in the oxic surface layer of the incubation without lugworms (oxic-0) and 90\% in the anoxic subsurface layer of the same experiment (anoxic-0). Most of them were affiliated with diatoms (Bacillariophyta) and only 3 phylotypes were assigned to other stramenopile taxa, namely bicosoecids and labyrinthulids (Supplement 1). The (unclassified) bicosoecids (2 phylotypes) and the labyrinthulids (1 phylotype) were only detected within the oxic sample and the subsurface burrow, respectively. In contrast, diatoms occurred throughout all analyzed samples. Dominant diatom taxa were Navicula, Thalassiosira and Odontella (Supplement 1), which were ubiquitously distributed in all samples. Other taxa like Gyrosigma were restricted to oxic sediment layers (Supplement 1).
Only a few phylotypes affiliated with fungi were detected in the investigated samples but analyses of their numerical distribution revealed distinctive patterns (Fig. 5, Supplement 1). While a similar number of phylotypes was detected in both unaltered oxic surface and anoxic subsurface samples, the diversity differed (1) decisively between both layers when the lugworms were present, and (2) between these layers and the lugworm burrow. Outside the lugworm burrows, only representatives of the Chytridiomycota and Dikarya contributed to the protistan community. Within the lugworm burrows, 1 phylotype affiliated with Dikarya, and also 1 phylotype belonging to the Neocallimastigomycota were detected. Rhizaria, a supergroup in the kingdom Eukarya comprising free-living protists such as foraminiferans, cercozoans, radiolarians and gromiids, have an uneven distribution in the individual samples (Fig. 5, Supplement 1). For example, 4 phylo- 


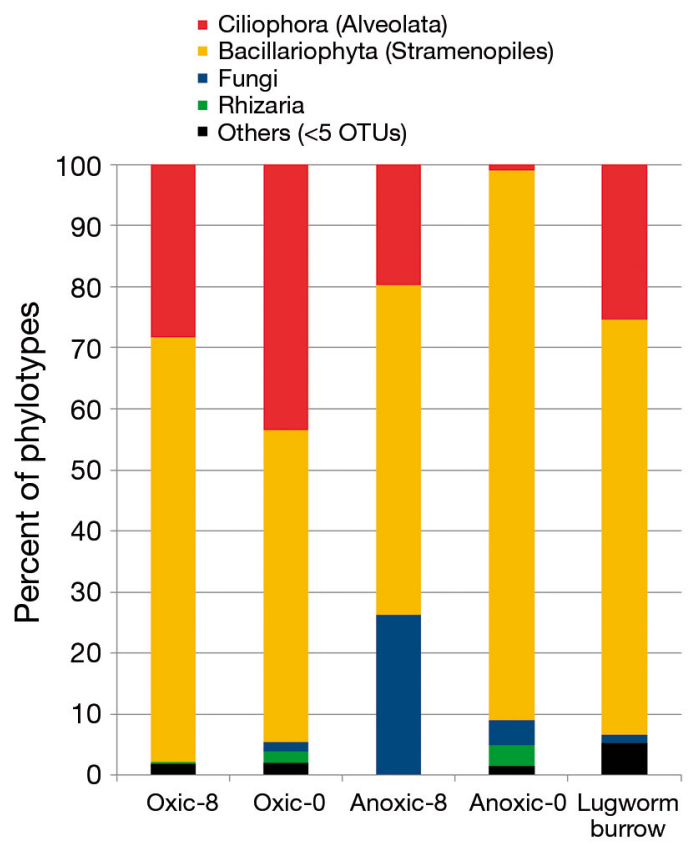

Fig. 5. Taxonomic composition of protistan communities in the 5 sediment samples analyzed (see Fig. 3 for definitions). The category 'others' refers to taxa contributing less than 5 operational taxonomic units (OTUs) to the overall protistan community, i.e. Apicomplexa, Dinophyceae, Amoebozoa, Apusozoa, Choanoflagellida, Cryptophyta, Dimorpha, Diplomonadida, Katablepharidophyta, Rhodophyta, Stramenopiles other than Bacillariophyta, and Chlorophyta. The most abundant taxonomic groups are ciliates (Ciliophora), diatoms (Bacillariophyta), fungi and rhizarians. The latter (Rhizaria) are a eukaryotic supergroup including diverse free-living protists such as cercozoans, radiolarians, foraminiferans and gromiids

types of the cercozoan genus Massisteria were detected under oxic conditions and only 1 phylotype under anoxic conditions. Two phylotypes of the cercozoan genus Thaumatomastix occurred in oxic surface sediments, whereas 4 phylotypes were detected in anoxic sediments.

\section{DISCUSSION}

Available studies assessing the effect of bioturbation on psammophilic microbial communities are mostly either restricted to bacteria (Asmus 1994, Bertics \& Ziebis 2009, 2010) or, in the case of microbial eukaryotes, to oxic surface sediments (Lei et al. 2010). However, benthic protists also occur under anoxic conditions in deeper sediment layers (facultative or obligate anaerobes, Fenchel 1996). Therefore, we attempted to obtain a more detailed picture of protistan diversity in disturbed (bioturbated) and undisturbed intertidal surface and subsurface sedi- ments in the German Wadden Sea. A high-throughput sequencing strategy (454 sequencing, pyrosequencing) allowed sample saturation in all samples but the lugworm burrow (Fig. 3), enabling unbiased comparisons of the individual samples.

The benthic microbial eukaryote communities were dominated by alveolates (ciliates), stramenopiles (diatoms), rhizaria (cercozoans), and fungi, with other taxon groups like apicomplexa, dinophyceae and amoebozoa being numerically negligible. As ciliates and diatoms accounted for up to $98 \%$ of the detected taxa, we will predominantly focus on these 2 groups of organisms to evaluate shifts in protistan community structures.

Irrespective of the presence of the lugworm Arenicola marina, protistan abundance (Fig. 2) and diversity (Table 2) was higher in oxic surface sediments compared to anoxic subsurface sediments. The observed decrease in ciliate diversity with sediment depth matches the well-known and described trend for ciliate abundances (Hartwig 1973, Berninger \& Epstein 1995). Hartwig (1973) reported a decline of up to $73 \%$ in ciliate abundance from the upper sediment layers to $5 \mathrm{~cm}$ depth in intertidal Sylt sediments and only $1 \%$ of the surficial epibenthic ciliate community abundance was detectable at $15 \mathrm{~cm}$ depth. This decline in ciliate abundance and diversity with depth was attributed to the absence of oxygen in subsurface sediment (Fenchel 1969, Berninger \& Epstein 1995, Fenchel \& Finlay 1995). In an earlier study, Fenchel (1996) demonstrated the effect of lugworm activities on the distribution of ciliated protists, using light microscopy identification. The author demonstrated a vertical distribution of ciliates and assumed that this spatial pattern is driven by oxygen gradients. Oxic surface sediments are usually colonized by high numbers of epibenthic ciliates and also interstitial ciliates. Among these are many bacterivorous ciliates, such as Tiarina and Pleuronema; diatom feeders, including Chlamydodon; herbivores that feed on flagellates and diatoms, like Condylostoma; carnivores, such as Trachelocera and Tracheloraphis; and also histophagous forms, such as Coleps and Prorodon, all of which were detected in the oxic surface sediments in our experiment (Supplement 1). Some of these species can live at the oxic-anoxic interface, and cope with alternating oxic and anoxic conditions (Hayward et al. 2003). Taxa such as Coleps, Pleuronema and most karyorelicteans (Carey 1992) can tolerate the anoxic sediments for short periods of time. The deeper (sulfidic) sediments are usually inhabited by a range of different ciliates that display a convergent evolution in their range of adaptations, 
such as symbiosis with bacteria or having mitochondria with anaerobic biochemistry or hydrogenosomes (Hackstein et al. 2008). Typical inhabitants include Plagiopyla, Metopus or Caenomorpha. Interestingly, none of these strictly anaerobic species were detected in this study. As such taxa were detected in previous molecular diversity surveys which applied the same molecular approach, including the PCR primers, as we did in this study (e.g. Stoeck \& Epstein 2003, Stoeck et al. 2010), we can exclude a methodological artifact. A possible explanation is that these obligate anaerobes were killed when the experimental plots were established and did not recolonize in population densities high enough for gene detection.

Besides ciliates, diatoms are key taxa in intertidal sediments and the most important benthic primary producers in temperate regions (MacIntyre et al. 1996, Blasutto et al. 2005). A vertical zonation of diatom abundance and diversity, as observed in our field experiments, has been attributed to abiotic factors like light availability, nutrient supplies, temperature, and oxygen concentration, as well as to biotic factors like grazing pressure, which many taxa escape by migrating into deeper sediment layers (Hartwig 1973, Kelly et al. 2001, Du et al. 2010, First \& Hollibaugh 2010). Specifically, pennate diatoms such as Navicula sp. are able to migrate along a vertical axis with an amplitude of several centimeters controlled by wave energy, light and chemical gradients (Kingston 1999, Rusch et al. 2001). Through vertical migrations, other diatoms like Nitzschia sp. escape irradiance, which on the sediment surface may be so strong as to inhibit photosynthesis (Kingston 1999, Du et al. 2010). Also, shear stress generated by tidal currents or waves as well as resuspension may force diatoms to migrate downwards into deeper sediment layers (MacIntyre et al. 1996). In addition to their active movement, diatoms are also washed into deeper sediment layers due to the influx of surface waters (Retraubun et al. 1996). Many diatoms, e.g. Amphora, can tolerate anoxic and, if present, sulfidic conditions in these subsurface sediments (First \& Hollibaugh 2010, Kamp et al. 2011), and some, e.g Thalassiosira, are even able to switch to a heterotrophic lifestyle for restricted periods of time (Harvey \& Macko 1997, Rusch et al. 2001). As photosynthetically inactive biomass (Kelly et al. 2001), they may perform vertical migrations to access rich inorganic nutrients in subsurface sediments (Kingston 2002).

Here, we have demonstrated that the presence of the lugworm has a strong impact on the protistan community structure: protistan diversity (Table 2,
Fig. 4) and abundance (Fig. 2) decreased markedly in comparison to control sediments without Arenicola marina. The overall weak overlap of protistan phylotypes between different locations within the sediment suggests specialized protistan communities adapted to specific environmental conditions. The impact of lugworms on the protistan community structure is likely to be caused by the combination of direct and indirect effects operating at different spatial and temporal scales: (1) trophic interactions in the benthic food web; (2) sediment-mediated effects; and (3) physical stress.

\section{Trophic interactions}

The lugworm is not a selective feeder (Rijken 1979, Zebe \& Schiedek 1996), but analyses of its foregut content have revealed a high proportion of diatoms in its diet (Retraubun et al. 1996). The residence time of sediment in the lugworm gut is comparatively short ( 15 min, Kermack 1955) and only labile organic matter is digested. To our knowledge, evidence for a top-down control of ciliates through micro-carnivore feeding types such as Arenicola is missing. This is most likely due to the destruction of soft-bodied ciliates during ingestion and digestion (Wickham et al. 2000, Lei et al. 2010) in contrast to the diatom frustules. Furthermore, the activities of Arenicola may indirectly affect bacterial community structures, as the lugworms decisively influence the quality of available organic matter in the sediment (Banta et al. 1999, Papaspyrou et al. 2007, Volkenborn et al. 2007a). This shift in prokaryote communities may then in turn result in structural changes in protistan communities, as many bacterivorous protists show a selective feeding behavior (pattern) (Glücksman et al. 2010).

\section{Sediment-mediated effects}

The established lugworm densities within the mesh bags ( 8 ind. $254 \mathrm{~cm}^{-2}$ ) corresponded to densities of $315 \mathrm{ind} . \mathrm{m}^{-2}$. This is much higher than average abundances reported for adult populations of Arenicola marina (20 to 40 ind. $\mathrm{m}^{-2}$, Reise 1985). However, densities of $>2000$ ind. $\mathrm{m}^{-2}$ can be found in dense beds of juvenile lugworms, and even within adult populations, denser patches are frequently found (authors' pers. obs.). Based on well documented knowledge of bioturbation activity, we can give rough quantitative estimates for the sediment reworked and 
the volume of water ventilated over the $6 \mathrm{wk}$ of this experiment. For the relatively small lugworms used in the present study (1.4 $\mathrm{g}$ fresh weight, $0.5 \mathrm{~g}$ dry weight) an individual sediment reworking rate of $0.5 \mathrm{~g} \mathrm{~h}^{-1}$ (dry weight sediment) and a pumping rate of $1 \mathrm{ml} \mathrm{min}{ }^{-1}$ seem realistic (Riisgård \& Banta 1998). For the sediment in our experiment, we calculated that $1 \mathrm{~g}$ dry sediment corresponded to $0.62 \mathrm{ml}$ wet sediment. Thus, with 8 lugworms being active during submersion, the volume of reworked sediment corresponds to a $7.25 \mathrm{~cm}$ thick sediment layer within each mesh bag. Time-integrated pumping rates correspond to 7.71 per mesh bag and day, which is more than twice the volume of pore water within each sediment bag. Given the widespread bioadvection that has been documented for lugworms (Wethey et al. 2008), it seems realistic that the entire pore water within the mesh bags was replaced about once per day.

\section{Physical stress}

In undisturbed sediments, microphytobenthos such as diatoms tend to form relatively stable structures like diatom films (Holland et al. 1974, Sahan et al. 2007), which in turn support a rich and abundant protistan community (Hamels et al. 2001, 2004, Sahan et al. 2007). The permanent reworking of the sediment poses a shear stress, which inhibits the formation of such biofilms. Moreover, changes in the chemical composition of the pore water as well as of the sediment chemistry as a result of the activities of Arenicola marina have been reported (Volkenborn et al. 2007a). We assume that factors such as increased exposure of subsurface biota to organic contaminants through bioturbation activity (Kure \& Forbes 1997) can also decrease protistan diversity and select for taxa with specific adaptations. However, this hypothesis needs to be verified, as the effect on protists of organic compounds that accumulate in pore water and in sediments is still elusive.

\section{The lugworm burrow as a unique subsurface environment}

The unique phylotype composition of protistan communities detected in the lugworm burrow supports the idea of the burrow as a distinct habitat (Kristensen \& Kostka 2005, Bertics \& Ziebis 2009). Studies of the burrows of other macrofaunal organisms have shown that even if geochemical conditions in burrows are equivalent to the sediment surface, the microbial communities in and around burrow walls are most likely unique (Bertics \& Ziebis 2009). Changes in microfaunal communities along sediment burrows have been reported previously (Bertics \& Ziebis 2009) and were explained with e.g. higher oxygen concentrations and/or a higher organic content compared to the surrounding sediment. Similar findings were reported by Fenchel (1996), and the author proposed that lugworm burrows and their development decisively influence the structure of ciliate communities in specific ways (Fenchel 1996). Yet, for protists, we lack a causal relationship between the 'elite structures' of the burrow (Reise 1981, p. 413) and changes in community structures. We assume that changes in bacterial communities (Kristensen \& Kostka 2005, Bertics \& Ziebis 2010, Bertics et al. 2010) as well as different nutrient regimes in the burrow (Retraubun et al. 1996) may support a rich and different protistan community compared to the oxic surface sediment. For example, Arenicola marina releases specific bacteria from its foregut into the headshaft, which are absent from the sediment surface (Grossmann \& Reichardt 1991). The funnel acts as a trap for detritus, algae debris and organic matter, which support a rich microbial food web ('gardening', Retraubun et al. 1996). Organic matter is transported down through the headshaft to the feeding pocket. There, the accumulation of organic material combined with permanent irrigation provides favorable conditions for bacteria and small bacterial grazers including protozoa, which are part of the lugworm diet (Reise 1981, Retraubun et al. 1996). Moreover, the physical structure of the burrow provides a stable physicochemical environment (Reise 1981), protecting protists from desiccation, extreme temperature variations and predation from epibenthic predators (Kristensen \& Kostka 2005). These factors may select for different and more diverse protistan communities compared to oxic surface sediments.

\section{CONCLUSIONS}

Analysis of the genetic diversity of protistan communities in intertidal sediment revealed highly diverse populations with surprisingly little overlap between different locations in the sediment. The presence of bioturbating lugworms reduced the abundance and diversity of protists in surface and subsurface sediments. However, the oxic sediment surrounding the lugworm burrow hosted a highly 
diverse protistan population, suggesting that infaunal burrows provide a unique ecological niche within intertidal sediments. The observed differences in the protistan community structure are thought to be driven by the combined effect of direct trophic effects and indirect, sediment-mediated effects operating on different spatial and temporal scales.

Acknowledgements. We thank M. Müller-Frey and C. Bauer for supporting sampling, T. Heinrich for supporting sample processing, and E. Herre for logistical support. The Alfred Wegener Institute for Polar and Marine Research in the Helmholtz Association provided laboratory space. The people at the Wadden Sea Station Sylt are thanked for their hospitality and support. Two anonymous reviewers made valuable comments on the manuscript. This study was funded by the Deutsche Forschungsgemeinschaft (grants STO414/3-1 and STO414/3-2), the University of Kaiserslautern, the National Science Foundation (grant OCE 0928002) and the Alfred Wegener Institute for Polar and Marine Research in the Helmholtz Association.

\section{LITERATURE CITED}

Aller RC (1982) The effects of macrobenthos on chemical properties of marine sediment and overlying water. In: McCall PL, Tevesz MJS (eds) Animal-sediment relations: the biogenic alteration of sediment, Vol 2, Topics in geobiology. Plenum Press, New York, p 53-102

Aller RC (1988) Benthic fauna and biogeochemical processes in marine sediments: the role of burrow structures. In: Blackburn TH, Sørensen J (eds) Nitrogen cycling in coastal marine environments. John Wiley \& Sons, Chichester, p 301-338

Aller RC (1994) Bioturbation and remineralization of sedimentary organic matter: effects of redox oscillation. Chem Geol 114:331-345

Amann RI, Binder BJ, Olson RJ, Chisholm SW, Devereux R, Stahl DA (1990) Combination of 16S rRNA-targeted oligonucleotide probes with flow cytometry for analyzing mixed microbial populations. Appl Environ Microbiol 56:1919-1925

Asmus H (1994) Benthic grazers and suspension feeders: which one assumes the energetic dominance in Königshafen? Helgol Mar Res 48:217-231

Banta GT, Holmer M, Jensen MH, Kristensen E (1999) Effects of two polychaete worms, Nereis diversicolor and Arenicola marina, on aerobic and anaerobic decomposition in a sandy marine sediment. Aquat Microb Ecol 19: 189-204

Baumfalk BA (1979) Heterogeneous grain size distribution in tidal flat sediment caused by bioturbation activity of Arenicola marina (Polychaeta). Neth J Sea Res 13: 428-440

Behnke A, Engel M, Christen R, Nebel M, Klein RR, Stoeck $\mathrm{T}$ (2011) Depicting more accurate pictures of protistan community complexity using pyrosequencing of hypervariable SSU rRNA gene regions. Environ Microbiol 13: 340-349

Berninger UG, Epstein SS (1995) Vertical distribution of benthic ciliates in response to the oxygen concentration in an intertidal North Sea sediment. Aquat Microb Ecol
9:229-236

Bertics VJ, Ziebis W (2009) Biodiversity of benthic microbial communities in bioturbated costal sediments is controlled by geochemical microniches. ISME J 3:1269-1285

- Bertics VJ, Ziebis W (2010) Bioturbation and the role of microniches for sulfate reduction in coastal marine sediments. Environ Microbiol 12:3022-3034

Bertics VJ, Sohm JA, Treude T, Chow CET, Capone DG, Fuhrman JA, Ziebis W (2010) Burrowing deeper into benthic nitrogen cycling: the impact of bioturbation on nitrogen fixation coupled to sulfate reduction. Mar Ecol Prog Ser 409:1-15

Blasutto O, Cibic T, Vittor C, Umani S (2005) Microphytobenthic primary production and sedimentary carbohydrates along salinity gradients in the lagoons of Grado and Marano (Northern Adriatic Sea). Hydrobiologia 550: $47-55$

Carey PG (1992) Marine interstitial ciliates. An illustrated key. Chapman \& Hall, London

> Chao A, Shen TJ (2003) Nonparametric estimation of Shannon's index of diversity when there are unseen species in sample. Environ Ecol Stat 10:429-443

> Chao A, Chazdon RL, Colwell RK, Shen TJ (2006) Abundance-based similarity indices and their estimation when there are unseen species in samples. Biometrics 62: 361-371

> Du GY, Oak JH, Li H, Chung IK (2010) Effect of light and sediment grain size on the vertical migration of benthic diatoms. Algae 25:133-140

> Epstein SS (1997) Microbial food webs in marine sediments. II. Seasonal changes in trophic interactions in a sandy tidal flat community. Microb Ecol 34:199-209

> Fenchel T (1969) The ecology of marine microbenthos. IV. Structure and function of the benthic ecosystem, its chemical and physical factors and the microfauna communities with special reference to the ciliated protozoa. Ophelia 6:1-182

> Fenchel T (1996) Worm burrows and oxic michroniches in marine sediments. 2. Distribution patterns of ciliated protozoa. Mar Biol 127:297-301

Fenchel T, Finlay BJ (1995) Ecology and evolution in anoxic worlds. Oxford University Press, New York, NY

- First M, Hollibaugh J (2010) Diel depth distributions of microbenthos in tidal creek sediments: high resolution mapping in fluorescently labeled embedded cores. Hydrobiologia 655:149-158

Flach EC (1992) Disturbance of benthic infauna by sediment-reworking activities of the lugworm Arenicola marina. Neth J Sea Res 30:81-89

Franklin RB, Mills AL (2003) Multi-scale variation in spatial heterogeneity for microbial community structure in an eastern Virginia agricultural field. FEMS Microbiol Ecol 44:335-346

Glücksman E, Bell T, Griffiths RI, Bass D (2010) Closely related protist strains have different grazing impacts on natural bacterial communities. Environ Microbiol 12: 3105-3113

Grossmann S, Reichardt W (1991) Impact of Arenicola marina on bacteria in intertidal sediments. Mar Ecol Prog Ser 77:85-93

Hackstein JHP, Graaf RM, Van Hellemond JJ, Tielens AGM (2008) Hydrogenosomes of anaerobic ciliates. In: Tachezy J (ed) Hydrogenosomes and mitosomes: mitochondria of anaerobic eukaryotes. Springer Verlag, Berlin, p 97-112 
Hamels I, Moens T, Muylaert K, Vyverman W (2001) Trophic interactions between ciliates and nematodes from an intertidal flat. Aquat Microb Ecol 26:61-72

Hamels I, Mussche H, Sabbe K, Muylaert K, Vyverman W (2004) Evidence for constant and highly specific active selection by benthic ciliates in mixed diatoms assemblages. Limnol Oceanogr 49:58-68

Hartwig E (1973) Die Ciliaten des Gezeiten-Sandstrandes der Nordseeinsel Sylt. II. Ökologie. In: Mikrofauna des Meeresbodens. Akademie der Wissenschaften und der Literatur, Mainz, p 3-171

> Harvey HR, Macko SA (1997) Kinetics of phytoplankton decay during simulated sedimentation: changes in lipids under oxic and anoxic conditions. Org Geochem 27: $129-140$

Hayward BH, Drosteb R, Epstein SS (2003) Interstitial ciliates: benthic microaerophiles or planktonic anaerobes? J Eukaryot Microbiol 50:356-359

Heip C, Engels P (1974) Comparing species diversity and evenness indices. J Mar Biol Assoc UK 54:559-563

Holland AF, Zingmark RG, Dean JM (1974) Quatitative evidence concerning the stabilization of sediment by marine benthic diatoms. Mar Biol 27:191-196

Hüttel M (1990) Influence of the lugworm Arenicola marina on porewater nutrient profiles of sand flat sediments. Mar Ecol Prog Ser 62:241-248

> Huse SM, Welch DM, Morrison HG, Sogin ML (2010) Ironing out the wrinkles in the rare biosphere through improved OTU clustering. Environ Microbiol 12:1889-1898

Kamp A, de Beer D, Nitsch JL, Lavik G, Stief P (2011) Diatoms respire nitrate to survive dark and anoxic conditions. Proc Natl Acad Sci USA 108:5649-5654

Kelly JA, Honeywill C, Paterson DM (2001) Microscale analysis of chlorophyll-a in cohesive, intertidal sediments: the implications of microphytobenthos distribution. J Mar Biol Assoc UK 81:151-162

Kermack DM (1955) The anatomy and physiology of the gut of the polychaete Arenicola marina. Proc Zool Soc Lond 125:347-381

Kingston MB (1999) Effect of light on vertical migration and photosyntheis of Euglena proxima (Euglenophyta). J Phycol 35:245-253

Kingston MB (2002) Effect of subsurface nutrient supplies on the vertical migration of Euglena proxima (Euglenophyta). J Phycol 38:872-880

Kristensen E (2001) Impact of polychaetes (Nereis spp. and Arenicola marina) on carbon biogeochemistry in costal marine sediments: a review. Geochem Trans 2:92-104

Kristensen E, Kostka JE (2005) Macrofaunal burrows and irrigation in marine sediment: microbiological and biogeochemical interactions. In: Kristensen E, Haese RR, Kostka JE (eds) Interactions between macro- and microorganisms in marine sediment, Costal Estuarine Stud 60. AGU, Washington, DC, p 125-157

Kuhnert J, Veit-Köhler G, Büntzow M, Volkenborn N (2010) Sediment-mediated effects of lugworms on intertidal meiofauna. J Exp Mar Biol Ecol 387:36-43

Kunin V, Engelbrektson A, Ochman H, Hugenholtz P (2010) Wrinkles in the rare biosphere: pyrosequencing errors can lead to artificial inflation of diversity estimates. Environ Microbiol 12:118-123

Kure LK, Forbes TL (1997) Impact of bioturbation by Arenicola marina on the fate of particle-bound fluoranthene. Mar Ecol Prog Ser 156:157-166

Le Gall S, Hassen MB, Le Gall P (1997) Ingestion of a bac- terivorous ciliate by the oyster Crassostrea gigas: protozoa as a trophic link between picoplankton and benthic suspension-feeders. Mar Ecol Prog Ser 152:301-306

Lei Y, Stumm K, Volkenborn N, Wickham S, Berninger UG (2010) Impact of Arenicola marina (Polychaeta) on the microbial assemblages and meiobenthos in a marine intertidal flat. Mar Biol 157:1271-1282

MacIntyre H, Geider R, Miller D (1996) Microphytobenthos: the ecological role of the 'secret garden' of unvegetated, shallow-water marine habitats. I. Distribution, abundance and primary production. Estuaries Coasts 19: 186-201

> Matsui GY, Ringelberg DB, Lovell CR (2004) Sulfate-reducing bacteria in tubes constructed by the marine infaunal polychaete Diopatra cuprea. Appl Environ Microbiol 70: 7053-7065

Medlin L. Elwood HJ, Stickel S, Sogin ML (1988) The characterization of enzymatically amplified eukaryotic 16Slike rRNA-coding regions. Gene 71:491-499

> Meysman FJR, Galaktionov OS, Middelburg JJ (2005) Irrigation patterns in permeable sediments induced by burrow ventilation: a case study of Arenicola marina. Mar Ecol Prog Ser 303:195-212

Na T, Gribsholt B, Galaktionov OS, Lee T, Meysman FJR (2008) Influence of advective bio-irrigation on carbon and nitrogen cycling in sandy sediments. J Mar Res 66: 691-722

> Nebel M, Pfabel C, Stock A, Dunthorn M, Stoeck T (2011) Delimiting operational taxonomic units for assessing ciliate environmental diversity using small-subunit rRNA gene sequences. Environ Microbiol Rep 3:154-158

> Nielsen OI, Kristensen E, Holmer M (2003) Impact of Arenicola marina (Polychaeta) on sediment sulfur dynamics. Aquat Microb Ecol 33:95-105

> Papaspyrou S, Gregersen T, Cox RP, Thessalou-Legaki M, Kristensen E (2005) Sediment properties and bacterial community in burrows of the ghost shrimp Pestarella tyrrhena (Decapoda: Thalassinidea). Aquat Microb Ecol 38:181-190

Papaspyrou S, Kristensen E, Christensen B (2007) Arenicola marina (Polychaeta) and organic matter mineralisation in sandy marine sediments: in situ and microcosm comparison. Estuar Coast Mar Sci 72:213-222

Quince C, Lanzen A, Curtis TP, Davenport RJ and others (2009) Accurate determination of microbial diversity from 454 pyrosequencing data. Nat Methods 6:639-641

Ranjard L, Richaume AS (2001) Quantitative and qualitative microscale distribution of bacteria in soil. Res Microbiol 152:707-716

> Reichardt W (1988) Impact of bioturbation by Arenicola marina on microbiological parameters in intertidal sediments. Mar Ecol Prog Ser 44:149-158

Reise K (1981) High abundance of small zoobenthos around biogenic structures in tidal sediments of the Wadden Sea. Helgol Mar Res 34:413-425

$>$ Reise K (1983) Experimental removal of lugworms from marine sand affects small zoobenthos. Mar Biol 74:327-332

Reise K (1985) Tidal flat ecology. Springer-Verlag, Berlin

> Reise K (1987) Spatial niches and long-term performance in meiobenthic Plathelminthes of an intertidal lugworm flat. Mar Ecol Prog Ser 38:1-11

Reise K, Ax P (1979) A macrofaunal 'thiobios' limited to the anaerobic sulfide system of marine sand does not exist. Mar Biol 54:225-237

Retraubun ASW, Dawson M, Evans SM (1996) The role of 
the burrow funnel in feeding processes in the lugworm Arenicola marina. J Exp Mar Biol Ecol 202:107-118

Riisgård HU, Banta GT (1998) Irrigation and deposit feeding by the lugworm Arenicola marina, characteristics and secondary effects on the environment. A review of our current knowledge. Vie Milieu 48:243-257

Rijken M (1979) Food and food uptake in Arenicola marina. Neth J Sea Res 13:406-421

Rusch A, Forster S, Huettel M (2001) Bacteria, diatoms and detritus in an intertidal sandflat subject to advective transport across the water-sediment interface. Biogeochemistry 55:1-27

Sahan E, Sabbe K, Creach V, Hernandez-Raquet G, Vyverman W, Stal LJ, Muyzer G (2007) Community structure and seasonal dynamics of diatom biofilms and associated grazers in intertidal mudflats. Aquat Microb Ecol 47: 253-266

Sherr EB, Caron DA, Sherr BF (1993) Staining of heterotrophic protists for visualization via epilfuorescence microscopy. In: Kemp PF, Sherr EB, Cole JJ (eds) Handbook of methods in aquatic microbial ecology. Lewis Publishers, Boca Raton, FL, p 213-227

Steward CC, Nold SC, Ringelberg DB, White DC, Lovell CR (1996) Microbial biomass and community structures in the burrows of bromophenol producing and nonproducing marine worms and surrounding sediments. Mar Ecol Prog Ser 133:149-165

Stoeck T, Epstein S (2003) Novel eukaryotic lineages inferred from small-subunit rRNA analyses of oxygendepleted marine environments. Appl Environ Microbiol 69:2657-2663

Stoeck T, Bass D, Nebel M, Christen R, Jones MD, Breiner HW, Richards TA (2010) Multiple marker parallel tag environmental DNA sequencing reveals a highly complex eukaryotic community in marine anoxic water. Mol

Editorial responsibility: Paul Snelgrove, St. John's, Newfoundland and Labrador, Canada
Ecol 19:21-31

> Timmermann K, Banta GT, Glud RN (2006) Linking Arenicola marina irrigation behavior to oxygen transport and dynamics in sandy sediments. J Mar Res 64:915-938

> Valdemarsen T, Wendelboe K, Egelund JT, Kristensen E, Flindt MR (2011) Burial of seeds and seedlings by the lugworm Arenicola marina hampers eelgrass (Zostera marina) recovery. J Exp Mar Biol Ecol 410:45-52

Volkenborn N, Reise K (2006) Lugworm exclusion experiment: responses by deposit feeding worms to biogenic habitat transformations. J Exp Mar Biol Ecol 330: 169-179

Volkenborn N, Hedtkamp SIC, van Beusekom JEE, Reise K (2007a) Effects of bioturbation and bioirrigation by lugworms (Arenicola marina) on physical and chemical sediment properties and implications for intertidal habitat succession. Estuar Coast Shelf Sci 74:331-343

Volkenborn N, Polerecky L, Hedtkamp S, Beusekom J, Beer D (2007b) Bioturbation and bioirrigation extend the open exchange regions in permeable sediments. Limnol Oceanogr 52:1898-1909

> Volkenborn N, Polerecky L, Hedtkamp SIC, Van Beusekom JEE, De Beer D (2010) Oscillatory porewater bioadvection in marine sediments induced by hydraulic activities of Arenicola marina. Limnol Oceanogr 55:1231-1247

- Wethey DS, Woodin SA, Volkenborn N, Reise K (2008) Porewater advection by hydraulic activities of lugworms, Arenicola marina: A field, laboratory and modeling study. J Mar Res 66:255-273

> Wickham S, Gieseke A, Berninger UG (2000) Benthic ciliate identification and enumeration: an improved methodology and its application. Aquat Microb Ecol 22:79-91

Zebe E, Schiedek D (1996) The lugworm Arenicola marina: a model of physiological adaptation to life in intertidal sediments. Helgol Mar Res 50:37-68

Submitted: February 15, 2012; Accepted: August 15, 2012 Proofs received from author(s): December 4, 2012 